Western University

Scholarship@Western

Chemistry Publications

Chemistry Department

Summer 6-29-2016

\title{
Aggregation-Induced Emission Enhancement in Boron Difluoride Complexes of 3-Cyanoformazanates
}

Ryan R. Maar

Joe Gilroy

jgilroy5@uwo.ca

Follow this and additional works at: https://ir.lib.uwo.ca/chempub

Part of the Chemistry Commons

Citation of this paper:

Maar, Ryan R. and Gilroy, Joe, "Aggregation-Induced Emission Enhancement in Boron Difluoride Complexes of 3-Cyanoformazanates" (2016). Chemistry Publications. 75.

https://ir.lib.uwo.ca/chempub/75 


\section{Journal of Materials Chemistry C}

\section{COMMUNICATION}

\section{Aggregation-Induced Emission Enhancement in Boron Difluoride Complexes of 3-Cyanoformazanates}

Received 00th January 20xx, Accepted 00th January 20xx

\begin{abstract}
DOI: $10.1039 / \times 0 x \times 00000 x$
\end{abstract}
www.rsc.org/

Boron difluoride $\left(\mathrm{BF}_{2}\right)$ complexes of 3-cyanoformazanates exhibit aggregation-induced emission enhancement in THF-water mixtures due to their severely twisted $\boldsymbol{N}$-aryl substituents which restrict intramolecular motion and $\pi$ stacking upon aggregation.

Molecules that exhibit aggregation-induced emission (AIE) or aggregation-induced emission enhancement (AIEE) have garnered significant attention due to their applicability to the fields of organic electronics, ${ }^{1,2}$ chemical sensing, ${ }^{3,4}$ and fluorescence cell imaging. ${ }^{1 b, 5,6}$ Typically, organic fluorophores experience attenuated emission intensity upon aggregation as a result of aggregation-caused quenching (ACQ). ${ }^{7}$ This arises due to the formation of strong intermolecular $\pi-\pi$ stacking interactions enabling the formation of excimers/exciplexes, which quench excited states via non-radiative pathways. ${ }^{1 b}$

The phenomenon of AIE was first described by Tang and co-workers as part of their work on 1-methyl-1,2,3,4,5pentaphenylsilole 1. ${ }^{8}$ Since its discovery, significant efforts have been invested toward the elucidation of the mechanism of AIE. Ultimately, it has been proposed that the restriction of intramolecular motions (RIM), which includes the restriction of intramolecular rotations and restriction of intramolecular vibrations, leads to the AIE phenomenon. ${ }^{5}$ Fervent work done by researchers worldwide has led to the development of numerous AIE luminogens (AIEgens), including: hydrocarbon- ${ }^{9}$ heteroatom-, ${ }^{10}$ and boron-containing systems. ${ }^{11,12}$ More recently, a variety of substituted tetraphenylethylenes $2^{13,14}$ and triphenylamines $\mathbf{3}^{15}$ have been widely studied.

Boron difluoride $\left(\mathrm{BF}_{2}\right)$ formazanates are an interesting class of molecular materials that possess tunable absorption, emission, and electrochemical properties through structural variation. ${ }^{16}$ The parent formazans $4,{ }^{17}$ are commonly used in cell viability assays, ${ }^{18}$ and are generally prepared via

${ }^{a}$ Department of Chemistry and the Centre for Advanced Materials and Biomaterials Research (CAMBR), The University of Western Ontario, London, Ontario, N6A 5B7 (Canada).E-mail: joe.gilroy@uwo.ca

†Electronic supplementary information (ESI) available: Synthesis and characterization details. CCDC 1455864. For ESI and crystallographic data in CIF or other electronic format see DOI: $10.1039 / \mathrm{x} 0 \mathrm{xx} 00000 \mathrm{x}$

straightforward aryl diazonium coupling reactions in aqueous media. $\mathrm{BF}_{2}$ formazanates have been incorporated into polymers, ${ }^{19}$ explored as electrochemiluminescent materials, ${ }^{20}$ used as precursors to $\mathrm{B}(\mathrm{I})$ carbenoid intermediates, ${ }^{21}$ and employed as fluorescent cell-imaging agents. ${ }^{22}$ Herein, we report the first examples of $\mathrm{BF}_{2}$ formazanates that demonstrate AIEE.

$\mathrm{BF}_{2}$ complex 5c was prepared in $96 \%$ yield according to a well-established synthetic methodology and the synthesis and characterization of $\mathbf{5 a}$ and $\mathbf{5 b}$ have been reported elsewhere. ${ }^{16,}$ 22 We chose these methoxy-substituted compounds for this study due to their superior emission properties, specifically, their relatively higher fluorescence quantum yields $\left(\Phi_{\mathrm{F}}\right)$ relative to other substituted $\mathrm{BF}_{2}$ formazanate derivatives. ${ }^{22}$ Complex $\mathbf{5 c}$ was fully characterized using multinuclear NMR spectroscopy, UV-vis absorption and emission spectroscopy, IR spectroscopy, cyclic voltammetry, and high-resolution mass spectrometry (Figs. S1-S4).

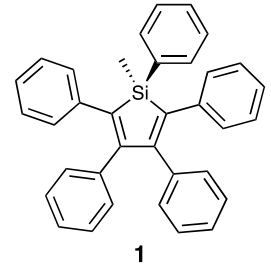

1

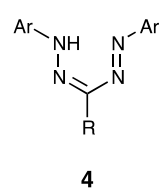

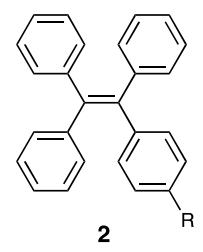

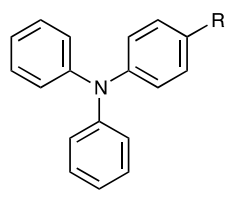

3

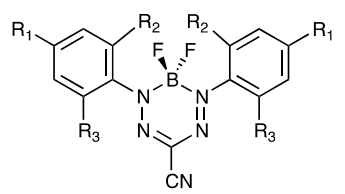

5a: $R_{1}=O M e, R_{2}=R_{3}=H$ 5b: $R_{1}=H, R_{2}=O M e, R_{3}=H$ 5c: $R_{1}=H, R_{2}=R_{3}=O M e$ 
Compounds $\mathbf{5 a}-\mathbf{c}$ absorb and emit within the visible region of the electromagnetic spectrum with a noticeable blue-shift in the wavelength of maximum absorbance $\left(\lambda_{\text {abs }}\right)$ when the $N$-aryl substituents were varied from 4-methoxyphenyl (5a: $\lambda_{\text {abs }}=$ $\left.556 \mathrm{~nm} ; \varepsilon=33,400 \mathrm{M}^{-1} \mathrm{~cm}^{-1}\right)$ to 2-methoxyphenyl $\left(\mathbf{5 b}: \lambda_{\mathrm{abs}}=\right.$ $\left.456 \mathrm{~nm} ; \varepsilon=10,100 \mathrm{M}^{-1} \mathrm{~cm}^{-1}\right)$ to 2,6-dimethoxyphenyl (5c: $\lambda_{\text {abs }}$ $=434 \mathrm{~nm} ; \varepsilon=13,900 \mathrm{M}^{-1} \mathrm{~cm}^{-1}$ ) (Fig. 1 and Table S1). This trend was also evident when examining the wavelength of maximum emission $\left(\lambda_{\mathrm{em}}\right)$ for $5 \mathbf{a}\left(\lambda_{\mathrm{em}}=662 \mathrm{~nm}\right), \mathbf{5 b}\left(\lambda_{\mathrm{em}}=\right.$ $590 \mathrm{~nm})$, and $5 \mathbf{c}\left(\lambda_{\mathrm{em}}=556 \mathrm{~nm}\right)$. The trends observed for the absorption/emission maxima are consistent with a previous report where the presence of ortho substituents led to twisting of the $N$-aryl substituents relative to the formazanate backbone and a blue-shift in absorption/emission maxima. ${ }^{22} \mathrm{~A}$ decrease in the $\Phi_{\mathrm{F}}$ was also observed for the same series of compounds: $5 \mathbf{a}$ $\left(\Phi_{\mathrm{F}}=0.46\right), \mathbf{5 b}\left(\Phi_{\mathrm{F}}=0.03\right)$ and $\mathbf{5 c}\left(\Phi_{\mathrm{F}}<0.01\right)$ (Figs. S5, S6, and Table S1). ${ }^{23}$ The solid-state structures of $\mathbf{5 a}-\mathbf{c}$ are comprised of carbon-nitrogen and nitrogen-nitrogen bonds with lengths between those of typical single and double bonds of the respective atoms, indicating a delocalized formazanate backbone consistent with previous reports (Tables S2 and S3). ${ }^{22}$ In addition, the dihedral angles between the $N$-aryl substituents and the formazanate backbone deviate from planarity from 4methoxyphenyl $\left(\mathbf{5 a}: 15.3^{\circ}, 21.4^{\circ} ; 47.7^{\circ}, 47.7^{\circ}\right)^{\ddagger}$ to $2-$

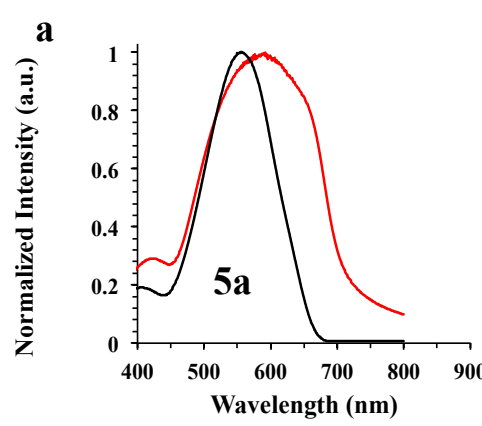

d

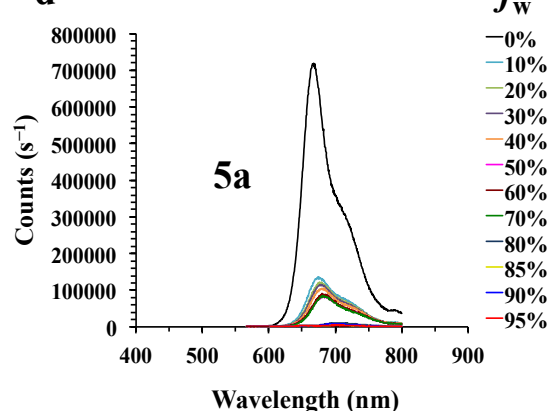

g
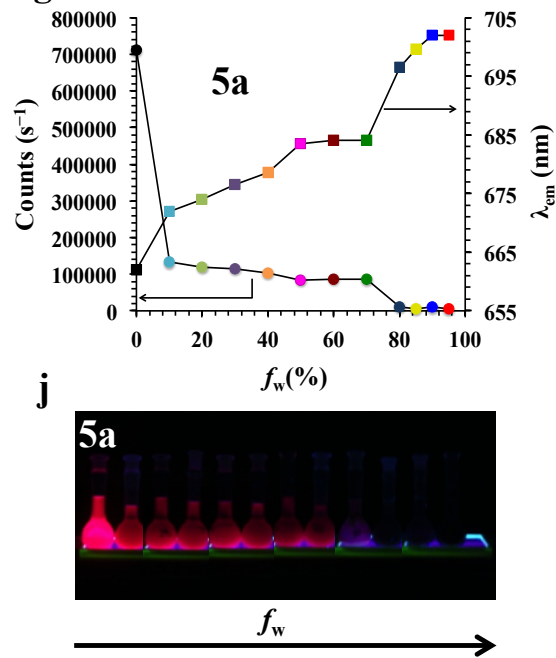
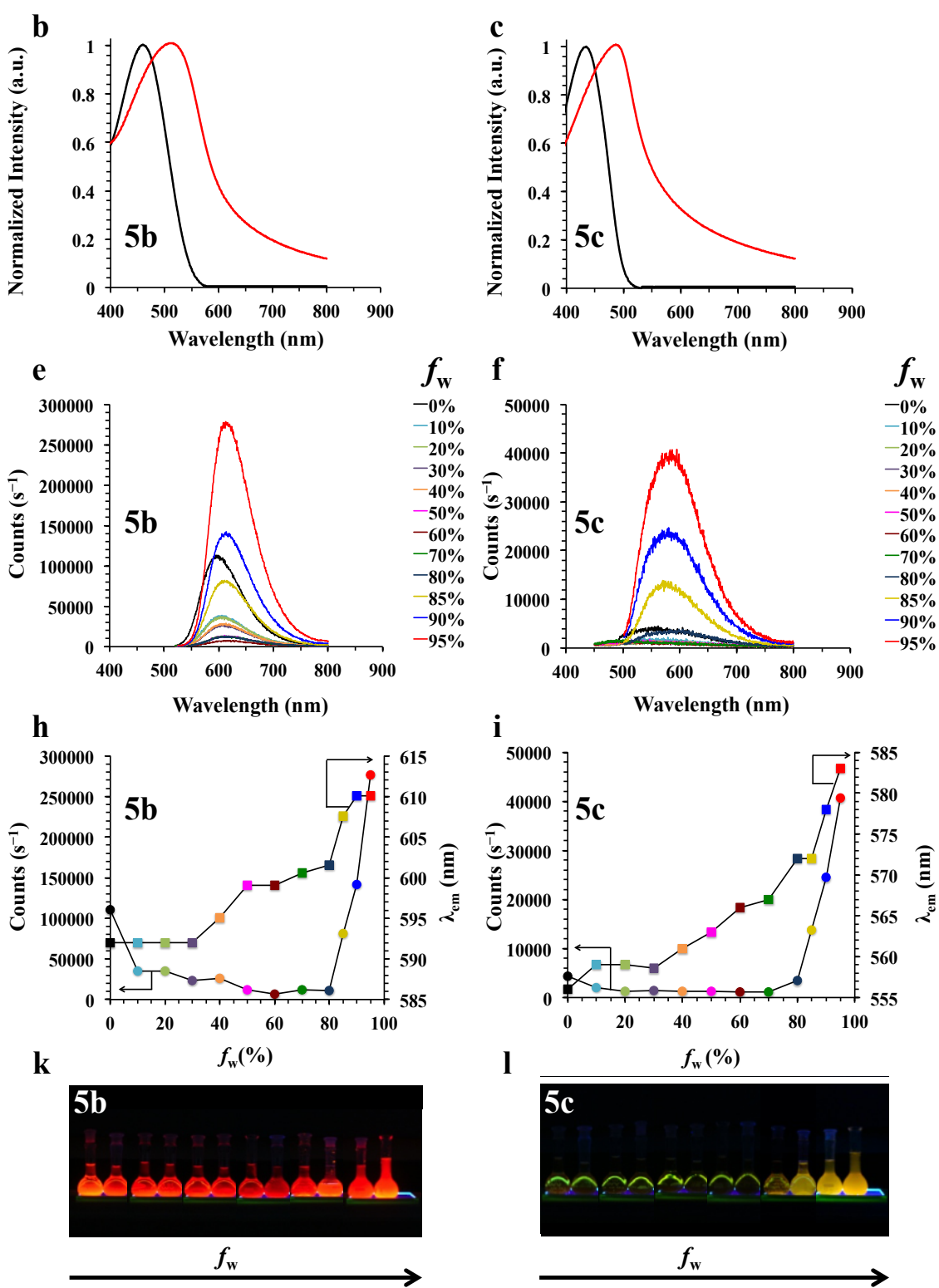

Fig. 1 Normalized UV-vis absorption spectra of $\mathbf{5 a}(\mathrm{a}), \mathbf{5 b}(\mathrm{b})$, and $\mathbf{5 c}(\mathrm{c})$ in pure THF solution (black line) and in a THF-water mixture with water volume fraction $\left(f_{\mathrm{w}}\right)$ of $95 \%$ (red line) $([\mathbf{5 a}-\mathbf{c}]=250 \mu \mathrm{M})$. UV-vis emission spectra of $\mathbf{5 a}(\mathrm{d}), \mathbf{5 b}(\mathrm{e})$, and $\mathbf{5 c}(\mathrm{f})$ in THF-water mixtures with $f_{\mathrm{w}}$ between $0 \%$ and $95 \%$ ([5a-c] $\left.=250 \mu \mathrm{M}\right)$. Changes in wavelength of maximum emission $\left(\lambda_{\text {em }}\right)$ (squares) and emission intensity (circles) of $\mathbf{5 a}(\mathrm{g}), \mathbf{5 b}(\mathrm{h})$, and $\mathbf{5 c}(\mathrm{i})$ in THF-water mixtures with $f_{\mathrm{w}}$ between $0 \%$ and $95 \%([\mathbf{5 a}-\mathbf{c}]=250 \mu \mathrm{M})$. Visual representation of the aggregation-caused quenching observed for $\mathbf{5 a}(\mathrm{j})$ and the aggregation-induced emission enhancement observed for $\mathbf{5 b}$ and $\mathbf{5 c}(\mathrm{k}, \mathrm{l})$. 
methoxyphenyl (5b: $\left.62.0^{\circ}, 60.5^{\circ}\right)$ to 2,6-dimethoxyphenyl (5c $74.6^{\circ}, 66.6^{\circ}$ ). These data indicate that $\mathbf{5 a}$ is more planar and therefore more electronically conjugated than $\mathbf{5 b}$ and $\mathbf{5 c}$ due to the absence of ortho methoxy substituents at the $N$-aryl rings on the 3-cyanoformazanate scaffold.

The electrochemical properties of 5c were explored using cyclic voltammetry (Fig. S7 and Table S1). The complex exhibited two reversible one-electron reductions within the electrochemical window of acetonitrile $\left(\mathrm{E}_{\text {red1 }}^{\circ}=-0.90 \mathrm{~V}\right.$, $\mathrm{E}_{\text {red2 }}^{\circ}=-2.09 \mathrm{~V}$ relative to the ferrocene/ferrocenium redox couple). The results were compared to data obtained for $\mathbf{5 a}$ $\left(\mathrm{E}^{\circ}{ }_{\text {red } 1}=-0.68 \mathrm{~V}, \mathrm{E}_{\text {red2 }}^{\circ}=-1.82 \mathrm{~V}\right)$ and $\mathbf{5 b}\left(\mathrm{E}_{\text {red } 1}^{\circ}=-0.75 \mathrm{~V}\right.$, $\mathrm{E}_{\text {red2 }}^{\circ}=-1.92 \mathrm{~V}$ ) and demonstrated that the introduction of ortho methoxy substituents made electrochemical reduction more difficult due to a less planar $\pi$ system. ${ }^{16,22}$

Exploration of the AIEE behaviour of 5a-c in THF-water mixtures with different volume fractions of water $\left(f_{\mathrm{w}}\right)$ revealed an interesting trend (Fig. 1 and Table S1). 5a is a typical organic fluorophore, which undergoes detrimental ACQ accompanied by a red-shift in both the absorbance and emission maxima of $36 \mathrm{~nm}$ and $40 \mathrm{~nm}$, respectively (Fig. 1 and Table $\mathrm{S} 1)$. A plausible explanation for the ACQ effect is the presence of intermolecular $\pi$-electron interactions that are facilitated by the planar orientation of the $N$-aryl substituents. This hypothesis is corroborated by the solid-state structure of 5a, which reveals short contacts (2.987-3.286 А) between the formazanate backbone and the cyano substituent of a neighbouring molecule (Fig. 2a). The frontier molecular orbitals of 5a have been shown previously to include significant orbital density on these structural features. ${ }^{16}$ In addition, there are numerous intermolecular interactions $[\mathrm{CH} \cdots \pi(2.763 \AA$ and $2.906 \AA), \mathrm{CH} \cdots \mathrm{O}(2.707 \AA$ and $3.060 \AA)$, and $\mathrm{CH} \cdots \mathrm{F}$ $(2.478-2.665 \AA)$ ], which may enable the formation of excimers (Fig. S8).

Both $\mathbf{5 b}$ and $\mathbf{5 c}$ act as AIEgens and undergo AIEE likely as a result of RIM (Fig. 1 and Table S1). Initially $\left(f_{\mathrm{w}}=0 \%\right), \mathbf{5 c}$ was weakly emissive and its emission intensity was further attenuated and red-shifted upon increasing $f_{\mathrm{w}}$. The decrease in emission intensity as the solvent mixture became increasingly polar was consistent with previously observed behaviour for similar dyes. ${ }^{16,22}$ Upon reaching a critical $f_{\mathrm{w}}(70 \%)$, the emission intensity was revitalized and further intensified until it reached a maximum value at $f_{\mathrm{w}}=95 \%$. Interestingly, $\lambda_{\text {abs }}$ and $\lambda_{\mathrm{em}}$ experience a net red-shift of $59 \mathrm{~nm}$ and $24 \mathrm{~nm}$ at $f_{\mathrm{w}}=95 \%$ compared to $f_{\mathrm{w}}=0 \%$ (Fig. 1 and Table S1). Based on the solidstate structure of $\mathbf{5 c}$, it is evident that there are multiple intermolecular interactions present: $\mathrm{CH} \cdots \pi(2.696 \AA$ and 2.885 $\AA), \mathrm{CH} \cdots \mathrm{O}(3.113 \AA$ and $3.125 \AA), \mathrm{CH} \cdots \mathrm{N}(2.552 \AA$ and 2.725 $\AA$ ), and CH...F (2.611 ̊̊) (Fig. S9). These interactions lock the conformation of the $N$-aryl substituents and prevent intramolecular motion. Complex $\mathbf{5 b}$ also exhibited decreased emission intensity upon the initial addition of water, which was rejuvenated at $f_{\mathrm{w}}=80 \%$. 5b exhibited red-shifts of $61 \mathrm{~nm}\left(\lambda_{\text {abs }}\right)$ and $20 \mathrm{~nm}\left(\lambda_{\mathrm{em}}\right)$ from $f_{\mathrm{w}}=0 \%$ to $f_{\mathrm{w}}=95 \%$ (Fig. 1 and Table S1) due to intermolecular interactions: $\mathrm{CH} \cdots \pi(2.655 \AA$ and $2.788 \AA), \mathrm{CH} \ldots \mathrm{O}(2.620 \AA$ and $2.794 \AA)$, and $\mathrm{CH} \ldots \mathrm{F}(2.398$ $\AA-2.509 \AA$ ) (Fig. S10). Red-shifted emission maxima are commonly observed for AIE-active molecules. ${ }^{24}$ While we are unable to identify the specific interactions leading to the redshift of the emission maxima observed for $\mathbf{5 b}$ and $\mathbf{5 c}$ (Figs. 2, S8-S10), we note that the potential $\pi$-stacking interactions observed in the solid-state structures of $\mathbf{5 b}$ and $\mathbf{5 c}$ have intermolecular distances outside the sum of the Van der Waal radii of the respective atoms (5b: $3.849-3.862 \AA$; $\mathbf{5 c}$ : 3.747-3.758 ^).

In summary, the readily accessible $\mathrm{BF}_{2}$ formazanates $\mathbf{5 a}-\mathbf{c}$ absorb and emit within the visible region of the electromagnetic spectrum. 5a is a typical organic fluorophore that experienced ACQ whereas $\mathbf{5 b}$ and $\mathbf{5 c}$ exhibited AIEE. Controlled addition of water into THF solutions of $\mathbf{5 b}$ and $\mathbf{5 c}$ initially resulted in decreased emission intensity before a critical $f_{\mathrm{w}}(\mathbf{5 b} \mathbf{b}: 80 \%$; $\mathbf{5 c}$ : $70 \%$ ) was reached and the emission intensity was invigorated $\mathbf{a}$

b

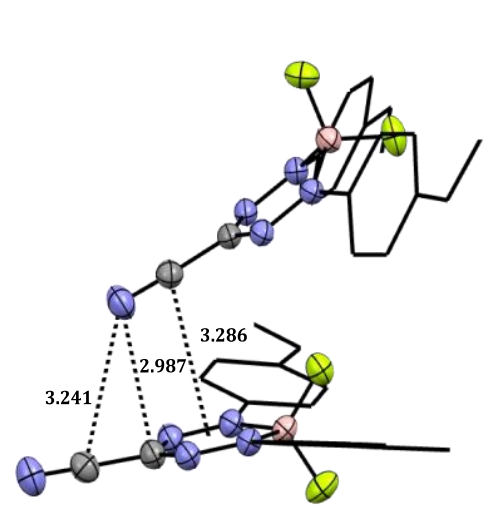

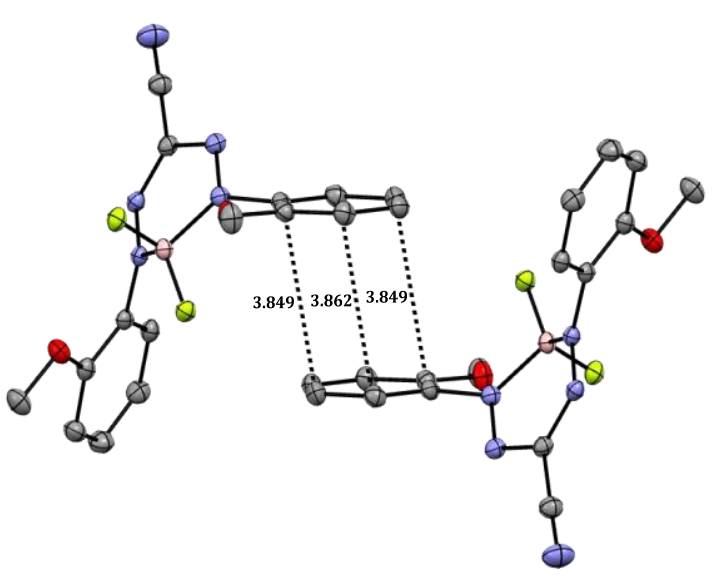

c

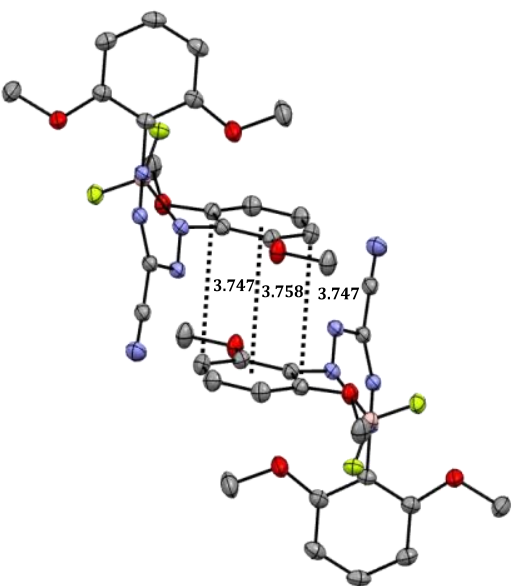

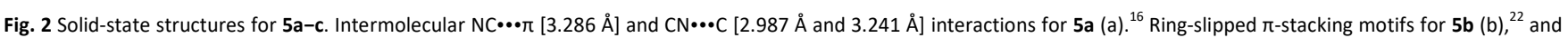
5c (c). Anisotropic displacement ellipsoids are shown at $50 \%$ probability. Hydrogen atoms have been omitted and $\mathrm{N}$-aryl substituents in (a) have been converted to wireframe style for clarity. All distances are quoted in $\AA$. 
and enhanced. Complex $\mathbf{5 b}$ exhibited a 3 -fold increase in emission at $f_{\mathrm{w}}=95 \%$, while $\mathbf{5 c}$ exhibited a 10 -fold increase under the same conditions. The degrees of enhancement were significant, but less dramatic than those observed for $\mathrm{CF}_{3}$ - and COOMe-substituted boron dipyrromethenes ( $c$ a. 40-fold increase in glycerol/methanol), which emit at similar wavelengths. ${ }^{25}$ The solid-state structure of $\mathbf{5 a}$ indicated the presence of strong intermolecular $\pi$-interactions, which resulted in ACQ, while 5b and 5c exhibited AIEE due to the restriction of intramolecular motion upon aggregation and do not appear to $\pi$ stack in the solid state. ${ }^{26}$ This work highlights the potential of $\mathrm{BF}_{2}$ formazanates as AIEgens. Subsequent studies will aim to further explore how substituent variation affects AIEE.

We would like to thank the University of Western Ontario, the Natural Science and Engineering Research Council (NSERC) of Canada (J.B.G.: DG, 435675 and R.R.M.: CGS-M Program), the Ontario Ministry of Research and Innovation (J.B.G.: ERA, ER14-10-147), and the Canadian Foundation for Innovation (J.B.G.: JELF, 33977) for funding this work Finally, we thank Profs. E.R. Gillies and M.S. Workentin for access to instrumentation within their laboratories and Ms. S.M. Barbon for performing X-ray crystallography studies.

\section{Notes and references}

ҒTwo crystallographically independent molecules were observed within the unit cell previously determined for $\mathbf{5 a}{ }^{16}$

1. a) J. Mei, N. L. C. Leung, R. T. K. Kwok, J. W. Y. Lam and B. Z. Tang, Chem. Rev., 2015, 115, 11718-11940; b) H. Wang, E. Zhao, J. W. Y. Lam and B. Z. Tang, Mater. Today, 2015, 18, 365-377.

2. a) W. Z. Yuan, Y. Gong, S. Chen, X. Y. Shen, J. W. Y. Lam, P. Lu, Y. Lu, Z. Wang, R. Hu, N. Xie, H. S. Kwok, Y. Zhang, J. Z. Sun and B. Z. Tang, Chem. Mater., 2012, 24, 1518-1528; b) J. Yang, J. Huang, N. Sun, Q. Peng, Q. Li, D. Ma and Z. Li, Chem. Eur. J., 2015, 21, 6862-6868; c) B. Liu, H. Nie, X. Zhou, S. Hu, D. Luo, D. Gao, J. Zou, M. Xu, L. Wang, Z. Zhao, A. Qin, J. Peng, H. Ning, Y. Cao and B. Z. Tang, Adv. Funct. Mater., 2016, 26, 776-783.

3. R. T. K. Kwok, C. W. T. Leung, J. W. Y. Lam and B. Z. Tang, Chem Soc. Rev., 2015, 44, 4228-4238.

4. a) M. Wang, G. Zhang, D. Zhang, D. Zhu and B. Z. Tang, J. Mater Chem., 2010, 20, 1858-1867; b) X. Dong, F. Hu, Z. Liu, G. Zhang and D. Zhang, Chem. Commun., 2015, 51, 3892-3895; c) G. Feng, Y. Yuan, H. Fang, R. Zhang, B. Xing, G. Zhang, D. Zhang and B. Liu, Chem. Commun., 2015, 51, 12490-12493.

5. J. Mei, Y. Hong, J. W. Y. Lam, A. Qin, Y. Tang and B. Z. Tang, $A d v$ Mater., 2014, 26, 5429-5479.

6. a) H. Shi, R. T. K. Kwok, J. Liu, B. Xing, B. Z. Tang and B. Liu, J. Am Chem. Soc., 2012, 134, 17972-17981; b) Y. Li, Y. Wu, J. Chang, M. Chen, R. Liu and F. Li, Chem. Commun., 2013, 49, 11335-11337.

7. J. B. Birks, Photophysics of Aromatic Molecules, Wiley, New York, 1970

8. J. Luo, Z. Xie, J. W. Y. Lam, L. Cheng, H. Chen, C. Qiu, H. S. Kwok, X. Zhan, Y. Liu, D. Zhu and B. Z. Tang, Chem. Commun., 2001, 17401741

9. a) J. W. Levell, A. Ruseckas, J. B. Henry, Y. Wang, A. D. Stretton, A. R. Mount, T. H. Galow and I. D. W. Samuel, J. Phys. Chem. A, 2010, 114 13291-13295; b) Z. He, L. Shan, J. Mei, H. Wang, J. W. Y. Lam, H. H. Y. Sung, I. D. Williams, X. Gu, Q. Miao and B. Z. Tang, Chem. Sci., 2015, 6, 3538-3543; c) Z. He, L. Zhang, J. Mei, T. Zhang, J. W. Y. Lam, Z. Shuai, Y. Q. Dong and B. Z. Tang, Chem. Mater., 2015, 27, 6601-6607.

10. a) B.-K. An, S.-K. Kwon, S.-D. Jung and S. Y. Park, J. Am. Chem. Soc., 2002, 124, 14410-14415; b) T. L. Bandrowsky, J. B. Carroll and J. Braddock-Wilking, Organometallics, 2011, 30, 3559-3569; c) Y. Ren and T. Baumgartner, Inorg. Chem., 2012, 51, 2669-2678; d) G. He, W. Torres Delgado, D. J. Schatz, C. Merten, A. Mohammadpour, L. Mayr, M. J. Ferguson, R. McDonald, A. Brown, K. Shankar and E. Rivard, Angew. Chem. Int. Ed., 2014, 53, 4587-4591.

11. a) Y. Yang, X. Su, C. N. Carroll and I. Aprahamian, Chem. Sci., 2012, 3, 610-613; b) R. Yoshii, A. Hirose, K. Tanaka and Y. Chujo, Chem. Eur. J., 2014, 20, 8320-8324; c) H. Naito, Y. Morisaki and Y. Chujo, Angew. Chem. Int. Ed., 2015, 54, 5084-5087; d) T. Butler, W. A. Morris, J. Samonina-Kosicka and C. L. Fraser, ACS Appl. Mater. Interfaces, 2016 , 8, 1242-1251; e) D. Wu, L. Shao, Y. Li, Q. Hu, F. Huang, G. Yu and G. Tang, Chem. Commun., 2016, 52, 541-544.

12. a) R. Hu, C. F. A. Gómez-Durán, J. W. Y. Lam, J. L. BelmonteVázquez, C. Deng, S. Chen, R. Ye, E. Peña-Cabrera, Y. Zhong, K. S. Wong and B. Z. Tang, Chem. Commun., 2012, 48, 10099-10101; b) T. T. Vu, M. Dvorko, E. Y. Schmidt, J.-F. Audibert, P. Retailleau, B. A. Trofimov, R. B. Pansu, G. Clavier and R. Méallet-Renault, J. Phys. Chem. C., 2013, 117, 5373-5385; c) S. Mukherjee and P. Thilagar, Chem. Eur. J., 2014, 20, 9052-9062; d) C. F. A. Gómez-Durán, R. Hu, G. Feng, T. Li, F. Bu, M. Arseneault, B. Liu, E. Peña-Cabrera and B. Z. Tang, ACS Appl. Mater. Interfaces, 2015, 7, 15168-15176.

13. Z. Zhao, J. W. Y. Lam and B. Z. Tang, J. Mater. Chem., 2012, 22, 23726-23740.

14. a) N. B. Shustova, B. D. McCarthy and M. Dincă, J. Am. Chem. Soc., 2011, 133, 20126-20129; b) X. Yan, H. Wang, C. E. Hauke, T. R. Cook, M. Wang, M. L. Saha, Z. Zhou, M. Zhang, X. Li, F. Huang and P. J. Stang, J. Am. Chem. Soc., 2015, 137, 15276-15286.

15. a) M. Yang, D. Xu, W. Xi, L. Wang, J. Zheng, J. Huang, J. Zhang, H. Zhou, J. Wu and Y. Tian, J. Org. Chem., 2013, 78, 10344-10359; b) M. Chen, H. Nie, B. Song, L. Li, J. Z. Sun, A. Qin and B. Z. Tang, J. Mater. Chem. C., 2016, 4, 2901-2908.

16. S. M. Barbon, P. A. Reinkeluers, J. T. Price, V. N. Staroverov and J. B. Gilroy, Chem. Eur. J., 2014, 20, 11340-11344.

17. a) A. W. Nineham, Chem. Rev., $1955, \mathbf{5 5}, 355-483$; b) A. S. Shawali and N. A. Samy, J. Adv. Res., 2015, 6, 241-254.

18. M. V. Berridge, P. M. Herst and A. S. Tan, Tetrazolium dyes as tools in cell biology: New insights into their cellular reduction, Elsevier, 2005.

19. a) S. Novoa, J. A. Paquette, S. M. Barbon, R. R. Maar and J. B. Gilroy, J. Mater. Chem. C., 2016, 4, 3987-3994; b) S. M. Barbon and J. B. Gilroy, Polym. Chem., 2016, 7, 3589-3598.

20. M. Hesari, S. M. Barbon, V. N. Staroverov, Z. Ding and J. B. Gilroy, Chem. Commun., 2015, 51, 3766-3769.

21. M.-C. Chang and E. Otten, Inorg. Chem., 2015, 54, 8656-8664

22. R. R. Maar, S. M. Barbon, N. Sharma, H. Groom, L. G. Luyt and J. B. Gilroy, Chem. Eur. J., 2015, 21, 15589-15599.

23. Attempts to determine the absolute fluorescence quantum yields for the aggregate solutions and thin films using the integrating sphere method were unsuccessful due to significant photon reabsorption by the samples.

24 a) R. Hu, E. Lager, A. Aguilar-Aguilar, J. Liu, J. W. Y. Lam, H. H. Y. Sung, I. D. Williams, Y. Zhong, K. S. Wong, E. Peña-Cabrera and B. Z. Tang, J. Phys. Chem. C., 2009, 113, 15845-15853; b) Q. Dai, W. Liu, L. Zeng, C.-S. Lee, J. Wu and P. Wang, CrystEngComm, 2011, 13, 4617 4624; c) C.-W. Liao, R. Rao M. and S.-S. Sun, Chem. Commun., 2015, 51, 2656-2659; d) R. S. Singh, R. K. Gupta, R. P. Paitandi, M. Dubey, G. Sharma, B. Koch and D. S. Pandey, Chem. Commun., 2015, 51, 9125-9128.

25. a) S. Choi, J. Bouffard and Y. Kim, Chem. Sci., 2014, 5, 751-755; b) S Kim, J. Bouffard and Y. Kim, Chem. Eur. J., 2015, 21, 17459-17465.

26. The thin-film absorption and emission spectra for $\mathbf{5 b}$ and $\mathbf{5 c}$ overlap significantly. However, the films appear to be highly luminescent under UV irradiation (Fig. S11). Complex 5a is non-emissive in the solid state. 


\title{
Supplementary Information
}

\author{
Aggregation-Induced Emission Enhancement in Boron Difluoride \\ Complexes of 3-Cyanoformazanates
}

Ryan R. Maar and Joe B. Gilroy*

Department of Chemistry and the Centre for Advanced Materials and Biomaterials

Research (CAMBR), The University of Western Ontario, London, Ontario, N6A 5B7

(Canada). Tel. +1-519-661-2111 ext. 81561. Email: joe.gilroy@uwo.ca

\section{Table of Contents}

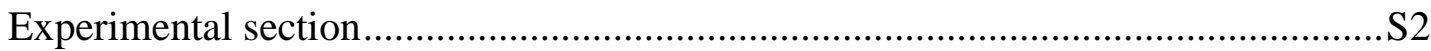

Spectroscopic and electrochemical data of $\mathrm{BF}_{2} 3$-cyanoformazanates $\mathbf{5 a}-\mathbf{c} \ldots \ldots \ldots \ldots . . . \mathrm{S} 5$

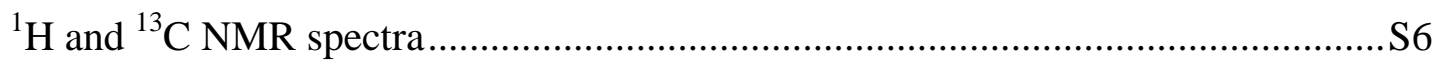

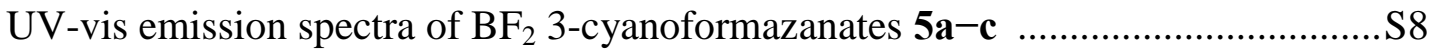

Detector correction provided by Photon Technology International ...........................S9

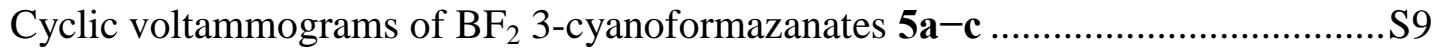

$\mathrm{X}$-ray crystallographic data of $\mathrm{BF}_{2}$ 3-cyanoformazanates $\mathbf{5 a}-\mathbf{c}$................................S10

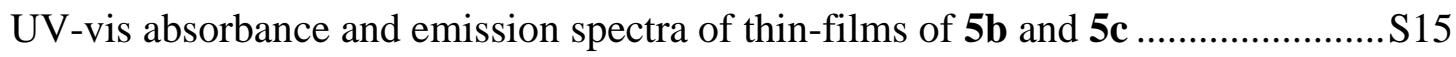

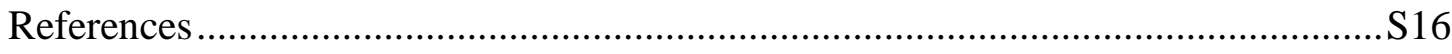




\section{Experimental}

\section{General Considerations}

Reagents were purchased from Sigma-Aldrich, Alfa Aesar, or Matrix Scientific and used as received unless otherwise specified. Solvents were purchased from Caledon Laboratories, dried using an Innovative Technologies Inc. solvent purification system, collected under vacuum, and stored under nitrogen atmosphere containing 4 Å molecular sieves. The synthesis, characterization, and X-ray crystallographic data of 1,5-bis(4methoxyphenyl)-3-cyanoformazan, 1,5-bis(2-methoxyphenyl)-3-cyanoformazan, 5a, and 5b have previously been reported. ${ }^{1,2}$ NMR spectra were recorded on $400 \mathrm{MHz}$ $\left({ }^{1} \mathrm{H}: 399.8 \mathrm{MHz},{ }^{11} \mathrm{~B}: 128.3 \mathrm{MHz},{ }^{19} \mathrm{~F}: 376.1 \mathrm{MHz}\right)$ or $600 \mathrm{MHz}\left({ }^{1} \mathrm{H}: 599.5 \mathrm{MHz},{ }^{13} \mathrm{C}\right.$ : $150.8 \mathrm{MHz}$ ) Varian INOVA spectrometers. ${ }^{1} \mathrm{H}$ NMR spectra were referenced to residual $\mathrm{CHCl}_{3}(\delta=7.27 \mathrm{ppm})$ and ${ }^{13} \mathrm{C}$ NMR spectra were referenced to $\mathrm{CDCl}_{3}(\delta=77.0 \mathrm{ppm})$.

${ }^{11} \mathrm{~B}$ spectra were referenced to $\mathrm{BF}_{3} \cdot \mathrm{OEt}_{2}$ at $\delta=0 \mathrm{ppm}$, and ${ }^{19} \mathrm{~F}$ spectra were referenced to $\mathrm{CFCl}_{3}$ at $\delta=0 \mathrm{ppm}$. Mass spectrometry data were recorded in positive-ion mode using a high-resolution Finnigan MAT 8200 spectrometer using electron impact ionization. Thinfilm samples of $\mathbf{5 b}$ and $\mathbf{5} \mathbf{c}$ were prepared by spin coating the appropriate sample onto a glass substrate from a $20 \mathrm{mg} \mathrm{mL}^{-1}$ solution of chlorobenzene. Samples were loaded onto the substrate using a $1 \mathrm{~mL}$ syringe and allowed to stand for $1 \mathrm{~min}$ before being spun at a rate of 3000 rpm for 30 seconds. Solution and thin-film UV-vis absorption spectra were recorded using a Cary 5000 UV-Vis-NIR spectrophotometer. For solution data, molar extinction coefficients were determined from the slope of a plot of absorbance against concentration using four solutions with known concentrations ranging between 10 and $100 \mu \mathrm{M}$. Infrared spectra were recorded on a $\mathrm{KBr}$ disk using a Bruker Vector 33 FT-IR spectrometer. Emission spectra were obtained using a Photon Technology International QM-4 SE spectrofluorometer. Excitation wavelengths were chosen based on absorption maxima from the respective UV-vis absorption spectrum in THF. Fluorescence quantum yields were calculated relative to ruthenium tris(bipyridine) hexafluorophosphate by methods described by Fery-Forgues and coworkers. ${ }^{3}$ 


\section{Electrochemical Methods}

Cyclic voltammetry experiments were performed with a Bioanalytical Systems Inc. (BASi) Epsilon potentiostat and analyzed using BASi Epsilon software. Typical electrochemical cells consisted of a three-electrode setup including a silver pseudo reference electrode, glassy carbon working electrode, and platinum counter electrode. Experiments were run at a scan rate of $100 \mathrm{mV} \mathrm{s}^{-1}$ in degassed acetonitrile solutions of

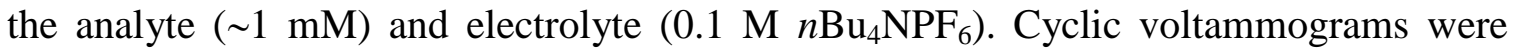
referenced relative to the ferrocene/ferrocenium redox couple $(\sim 1 \mathrm{mM}$ internal standard $)$ and corrected for internal cell resistance using the BASi Epsilon software.

\section{X-ray Crystallography Methods}

Single crystals for X-ray diffraction studies of $\mathbf{5 c}$ were grown by slow diffusion of hexanes into a saturated solution of the compound in dichloromethane. The samples were mounted on a Mitegen polyimide micromount with a small amount of Paratone $\mathrm{N}$ oil. X-ray measurements for 5c were made on a Nonius KappaCCD Apex2 at a temperature of $110 \mathrm{~K}$. The data collection strategy was a number of $\omega$ and $\varphi$ which collected data over a range of angles, $2 \theta$. The frame integration was performed using SAINT. ${ }^{4}$ The resulting raw data was scaled and absorption corrected using a multi-scan averaging of symmetry equivalent data using SADABS. ${ }^{5}$ The structure was solved by using a dual space methodology using the SHELXT program. ${ }^{6}$ All non-hydrogen atoms were obtained from the initial solution. The hydrogen atoms were introduced at idealized positions and were allowed to refine isotropically. The structural model was fit to the data using full matrix least-squares based on $F^{2}$. The calculated structure factors included corrections for anomalous dispersion from the usual tabulation. The structure was refined using the SHELXL-2014 program from the SHELXTL program package. ${ }^{7}$

CCDC-1455864 and Tables S2 and S3 contain the supporting crystallographic data for this paper. This data can be obtained free of charge from The Cambridge Crystallographic Data Centre via www.ccdc.cam.ac.uk/data_request/cif. 


\section{Preparation of 1,5-bis(2,6-dimethoxyphenyl)-3-cyanoformazan}

In air, cyanoacetic acid $(0.51 \mathrm{~g}, 6.0 \mathrm{mmol})$ and sodium hydroxide $(3.27 \mathrm{~g}, 81.8 \mathrm{mmol})$ were dissolved in deionized water $(55 \mathrm{~mL})$. The colourless solution was cooled to $0{ }^{\circ} \mathrm{C}$ and stirred for $1 \mathrm{~h}$. In a separate flask, 2,6-dimethoxyaniline $(1.80 \mathrm{~g}, 11.8 \mathrm{mmol})$ was combined with concentrated hydrochloric acid $(3.50 \mathrm{~mL}, 42.0 \mathrm{mmol})$ in deionized water $(20 \mathrm{~mL})$ and stirred for $30 \mathrm{~min}$ at $0 \quad{ }^{\circ} \mathrm{C}$. A solution of sodium nitrite $(0.92 \mathrm{~g}, 13 \mathrm{mmol})$ in deionized water $(3 \mathrm{~mL})$ was cooled to $0{ }^{\circ} \mathrm{C}$ in an ice bath for 15 min before being added dropwise over a $30 \mathrm{~min}$ period to the 2,6-dimethoxyaniline solution. The resulting red/yellow diazonium salt solution was stirred for $45 \mathrm{~min}$ at $0{ }^{\circ} \mathrm{C}$ before it was added to the alkaline cyanoacetic acid solution described above over a 20 min period. Upon addition, the solution turned blood red and a precipitate of the same colour formed. The mixture was stirred for $3 \mathrm{~h}$ before the precipitate was collected by vacuum filtration to afford a red solid. The filtrate was neutralized with $1 \mathrm{M} \mathrm{HCl}$, extracted into dichloromethane $(3 \times 100 \mathrm{~mL})$, washed with deionized water $(3 \times 100 \mathrm{~mL})$ and brine $(1 \times 150 \mathrm{~mL})$, dried over $\mathrm{MgSO}_{4}$, gravity filtered, and concentrated in vacuo to afford a second portion of 1,5-bis(2,6-dimethoxyphenyl)-3-cyanoformazan as a red solid. Both solids were combined and purified by flash column chromatography (dichloromethane, neutral alumina) and then recrystallized from methanol to afford 1,5bis(2,6-dimethoxyphenyl)-3-cyanoformazan as a dark-red microcrystalline solid. Yield $=2.02 \mathrm{~g}, 92 \%$; Mp: $133-135{ }^{\circ} \mathrm{C} .{ }^{1} \mathrm{H}$ NMR $\left(599.5 \mathrm{MHz}, \mathrm{CDCl}_{3}\right): \delta 12.60(\mathrm{~s}, 1 \mathrm{H}$, $\mathrm{N} \underline{H}), 7.22\left(\mathrm{t},{ }^{3} J_{\mathrm{HH}}=8 \mathrm{~Hz}, 2 \mathrm{H}, \operatorname{aryl} \mathrm{C} \underline{H}\right), 6.66\left(\mathrm{~d},{ }^{3} J_{\mathrm{HH}}=8 \mathrm{~Hz}, 4 \mathrm{H}, \operatorname{aryl} \mathrm{C} \underline{H}\right), 3.89(\mathrm{~s}, 12 \mathrm{H}$, $\left.\mathrm{OC} \underline{H}_{3}\right) .{ }^{13} \mathrm{C}\left\{{ }^{1} \mathrm{H}\right\} \mathrm{NMR}\left(150.8 \mathrm{MHz}, \mathrm{CDCl}_{3}\right): \delta 153.5,129.5,126.8,125.6,114.9,105.0$, 56.4. FT-IR (KBr): 3063 (m), 3011 (m), 2960 (m), 2838 (m), 2221 (s), 1589 (s), 1522 (s),

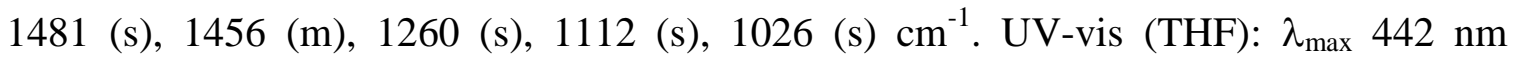
$\left(\varepsilon=9,200 \mathrm{M}^{-1} \mathrm{~cm}^{-1}\right) ; 362 \mathrm{~nm}\left(18,675 \mathrm{M}^{-1} \mathrm{~cm}^{-1}\right)$. MS (EI = +ve mode): exact mass calculated for $\left[\mathrm{C}_{18} \mathrm{H}_{19} \mathrm{~N}_{5} \mathrm{O}_{4}\right]^{+}:$369.1437; exact mass found: 369.1431; difference: $-1.6 \mathrm{ppm}$.

\section{Preparation of $\mathrm{BF}_{2}$ Formazanate Complex $5 \mathrm{c}\left(\mathrm{Ar}_{1}=\mathrm{Ar}_{5}=2,6\right.$-dimethoxyphenyl):}

Under $\mathrm{N}_{2}$, 1,5-bis(2,6-dimethoxyphenyl)-3-cyanoformazan (1.04 g, $2.86 \mathrm{mmol}$ ) was dissolved in dry toluene $(100 \mathrm{~mL})$ before anhydrous triethylamine $(2.61 \mathrm{~g}, 3.60 \mathrm{~mL}$, 
$25.8 \mathrm{mmol}$ ) was added and the solution was stirred for $30 \mathrm{~min}$. Boron trifluoride diethyl etherate $(6.09 \mathrm{~g}, 5.30 \mathrm{~mL}, 42.9 \mathrm{mmol})$ was then added and the solution was heated to $80{ }^{\circ} \mathrm{C}$ for $18 \mathrm{~h}$. The colour of the solution gradually changed from dark red to orange/yellow. At this time, the solution was cooled to $20{ }^{\circ} \mathrm{C}$ and deionized water $(25 \mathrm{~mL})$ was added to quench any reactive boron-containing species. The mixture was washed with deionized water $(3 \times 50 \mathrm{~mL})$, dried over $\mathrm{MgSO}_{4}$, gravity filtered, and concentrated in vacuo to afford $\mathbf{5 c}$ as an orange solid. The crude solid was purified via flash column chromatography (dichloromethane, neutral alumnia) and triturated with icecold methanol to afford $\mathbf{5 c}$ as bright orange microcrystalline solid. Yield $=1.15 \mathrm{~g}, 96 \%$; Mp: $184-186{ }^{\circ} \mathrm{C} .{ }^{1} \mathrm{H}$ NMR $\left(599.5 \mathrm{MHz}, \mathrm{CDCl}_{3}\right): \delta 7.33\left(\mathrm{t},{ }^{3} J_{\mathrm{HH}}=8 \mathrm{~Hz}, 2 \mathrm{H}\right.$, aryl $\left.\mathrm{C} \underline{H}\right)$, $6.61\left(\mathrm{~d},{ }^{3} J_{\mathrm{HH}}=8 \mathrm{~Hz}, 4 \mathrm{H}\right.$, aryl $\left.\mathrm{C} \underline{H}\right), 3.82\left(\mathrm{~s}, 12 \mathrm{H}, \mathrm{OC} \underline{H}_{3}\right) .{ }^{13} \mathrm{C}\left\{{ }^{1} \mathrm{H}\right\} \mathrm{NMR}(150.8 \mathrm{MHz}$, $\left.\mathrm{CDCl}_{3}\right): \delta 156.1,131.8,121.4,114.0,104.5,56.4 .{ }^{11} \mathrm{~B} \mathrm{NMR}\left(128.3 \mathrm{MHz}, \mathrm{CDCl}_{3}\right)$ : $\delta-2.6\left(\mathrm{t},{ }^{1} J_{\mathrm{BF}}=16 \mathrm{~Hz}\right) .{ }^{19} \mathrm{~F}\left(376.1 \mathrm{MHz}, \mathrm{CDCl}_{3}\right): \delta-162.2\left(\mathrm{q},{ }^{1} J_{\mathrm{FB}}=16 \mathrm{~Hz}\right)$. FT-IR (KBr): 3075 (m), 2956 (s), 2942 (s), 2830 (m), 2219 (m), 1432 (s), 1330 (s), 1245 (s), 1026 (s), 943 (s) cm $\mathrm{cm}^{-1}$. UV-vis (THF): $\lambda_{\max } 434 \mathrm{~nm}\left(\varepsilon=13,900 \mathrm{M}^{-1} \mathrm{~cm}^{-1}\right)$. MS (EI = +ve mode): exact mass calculated for $\left[\mathrm{C}_{18} \mathrm{H}_{18} \mathrm{BF}_{2} \mathrm{~N}_{5} \mathrm{O}_{4}\right]^{+}: 417.1420$; exact mass found: 417.1421 ; difference: $+0.2 \mathrm{ppm}$.

Table S1 Spectroscopic and electrochemical data for $\mathrm{BF}_{2}$ formazanates $\mathbf{5 a}-\mathbf{c}$.

\begin{tabular}{|c|c|c|c|c|c|c|c|c|}
\hline \multicolumn{7}{|c|}{ In solution } & \multicolumn{2}{|c|}{ Thin film } \\
\hline & $\begin{array}{l}\lambda_{\mathrm{abs}}(\mathrm{nm}) \\
\varepsilon\left(\mathrm{M}^{-1} \mathrm{~cm}^{-1}\right)^{a}\end{array}$ & $\begin{array}{l}\lambda_{\mathrm{em}}(\mathrm{nm}) \\
\Phi_{\mathrm{F}}, \mathrm{THF}^{a, b}\end{array}$ & $\begin{array}{l}\lambda_{\mathrm{abs}}(\mathrm{nm}) \\
\operatorname{Aggr}^{c}\end{array}$ & $\begin{array}{l}\lambda_{\mathrm{em}}(\mathrm{nm}) \\
\operatorname{Aggr}^{c}\end{array}$ & $\begin{array}{l}E_{\text {red1 }}^{\circ}{ }^{d} \\
(\mathrm{~V})\end{array}$ & $\begin{array}{l}E_{\text {red2 }}^{\circ}{ }^{\circ} \\
(\mathrm{V})\end{array}$ & $\begin{array}{l}\lambda_{\mathrm{abs}} \\
(\mathrm{nm}) \\
\end{array}$ & $\begin{array}{l}\lambda_{\text {em }} \\
(\mathrm{nm}) \\
\end{array}$ \\
\hline $5 \mathbf{a}^{1}$ & $556,33,400$ & $662,0.46$ & 592 & 702 & -0.68 & -1.82 & - & - \\
\hline $5 b^{2}$ & $456,10,100$ & $590,0.03$ & 517 & 610 & -0.75 & -1.92 & 476 & 616 \\
\hline $5 c$ & $434,13,900$ & $556,<0.01$ & 493 & 580 & -0.90 & -2.09 & 443 & 584 \\
\hline
\end{tabular}

${ }^{a} \overline{\text { Spectra were recorded for } 10 \mu \mathrm{M} \text { solutions in dry, degassed THF. }{ }^{b} \text { Quantum yield experiments were }}$ measured using ruthenium tris(bipyridine) hexafluorophosphate as a relative standard ${ }^{3,8}$ and corrected for detector non-linearity (Fig. S6). ${ }^{c}$ Spectra were recorded at a concentration of $250 \mu \mathrm{M}$ in a THF-water mixture with water volume fraction of $95 \%$ at $25{ }^{\circ} \mathrm{C}$. ${ }^{d} \mathrm{Cyclic}$ voltammetry experiments were conducted in dry, degassed acetonitrile containing $\sim 1 \mathrm{mM}$ analyte and $0.1 \mathrm{M} n \mathrm{Bu}_{4} \mathrm{NPF}_{6}$ at a scan rate of $100 \mathrm{mV} \mathrm{s}^{-1}$. All voltammograms were internally referenced to the ferrocene/ferrocenium redox couple. 


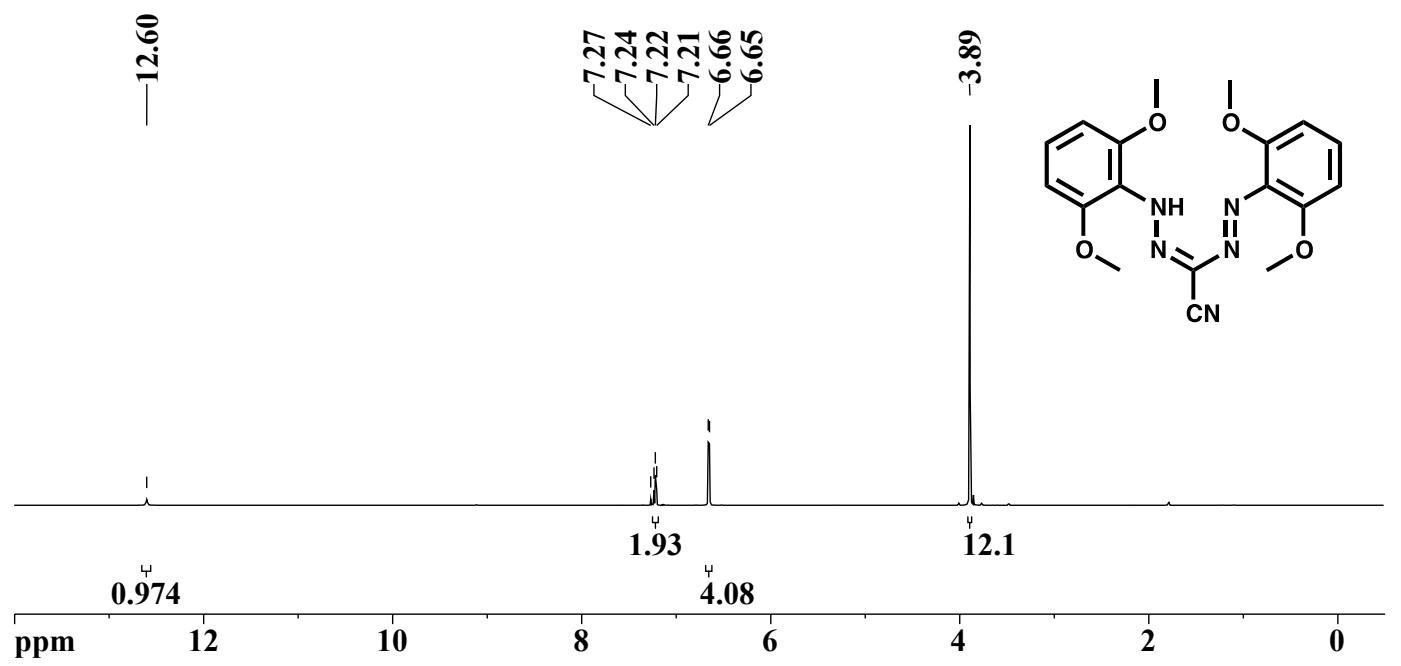

Fig. S1 ${ }^{1} \mathrm{H}$ NMR spectrum of 1,5-bis(2,6-dimethoxyphenyl)-3-cyanoformazan in $\mathrm{CDCl}_{3}$.

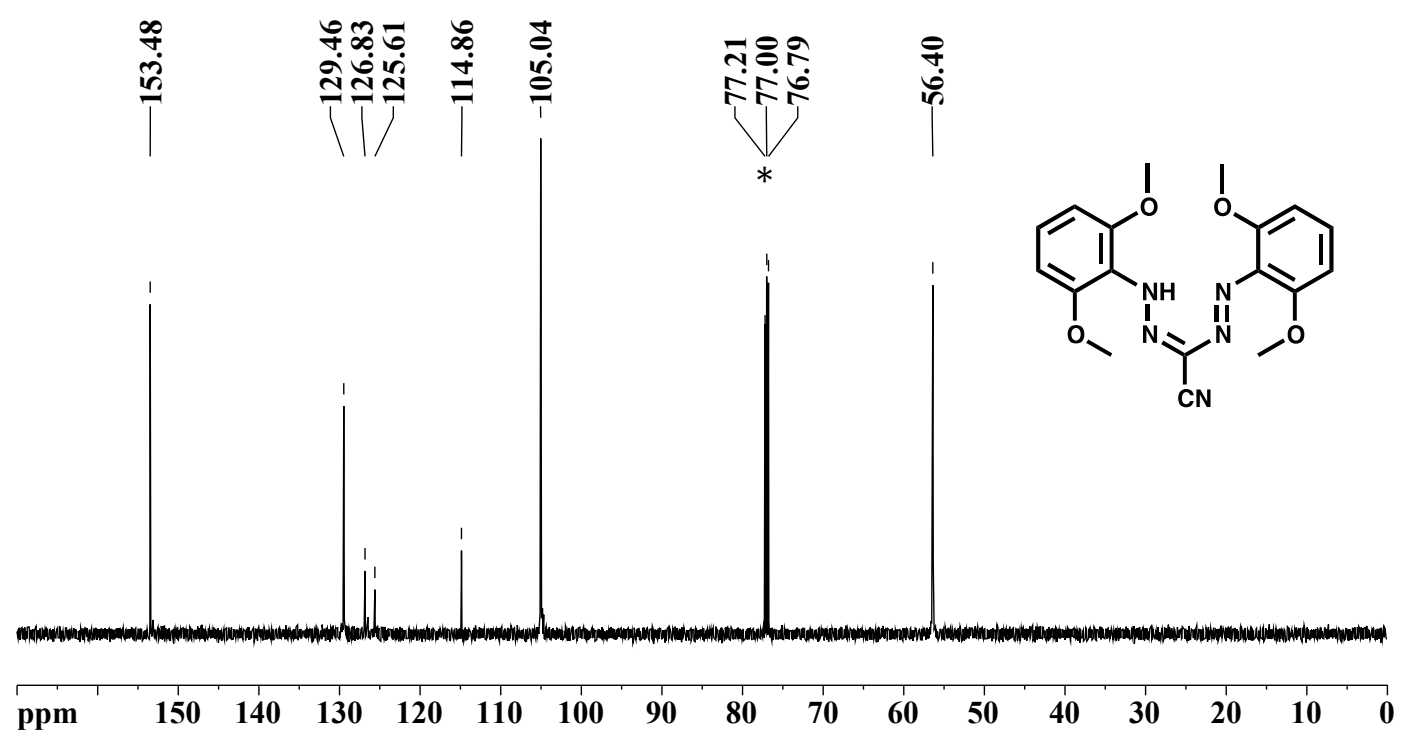

Fig. S2 ${ }^{13} \mathrm{C}\left\{{ }^{1} \mathrm{H}\right\}$ NMR spectrum of 1,5-bis(2,6-dimethoxyphenyl)-3-cyanoformazan in $\mathrm{CDCl}_{3}$. Asterisk denotes solvent signal. 


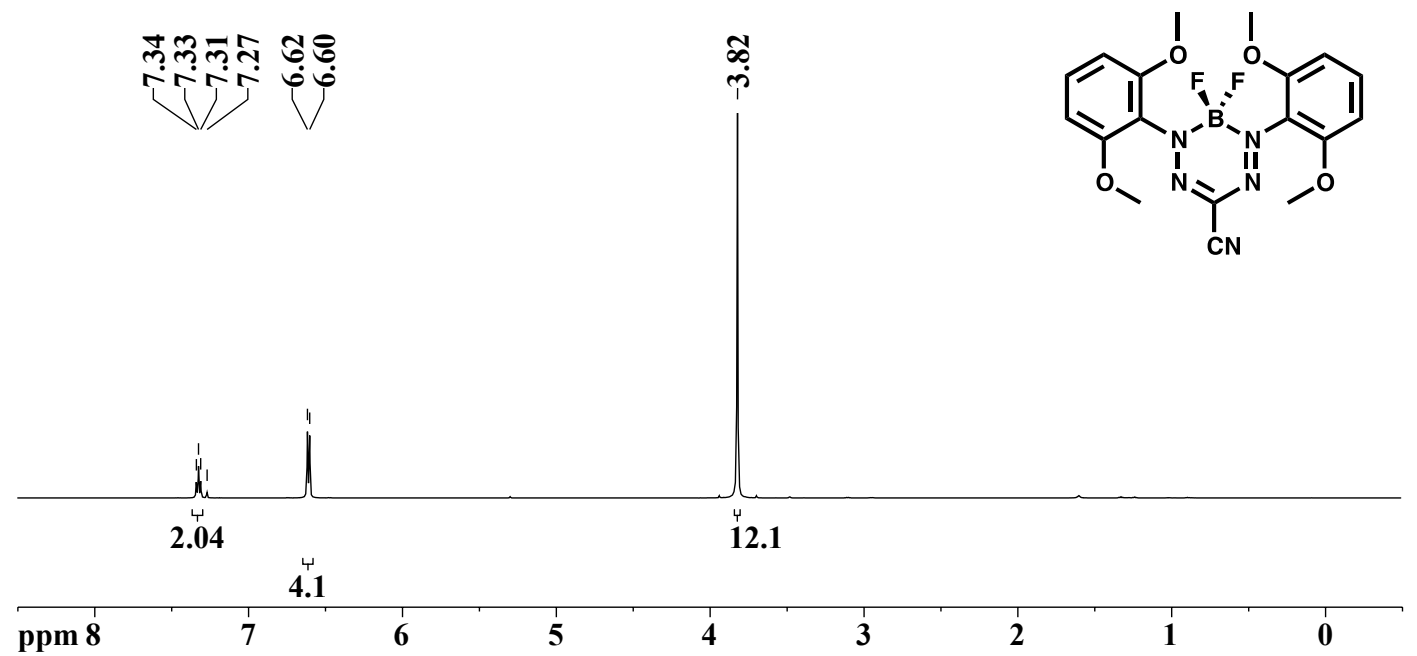

Fig. S3 ${ }^{1} \mathrm{H}$ NMR spectrum of $\mathrm{BF}_{2} 3$-cyanoformazanate $\mathbf{5 c}$ in $\mathrm{CDCl}_{3}$.

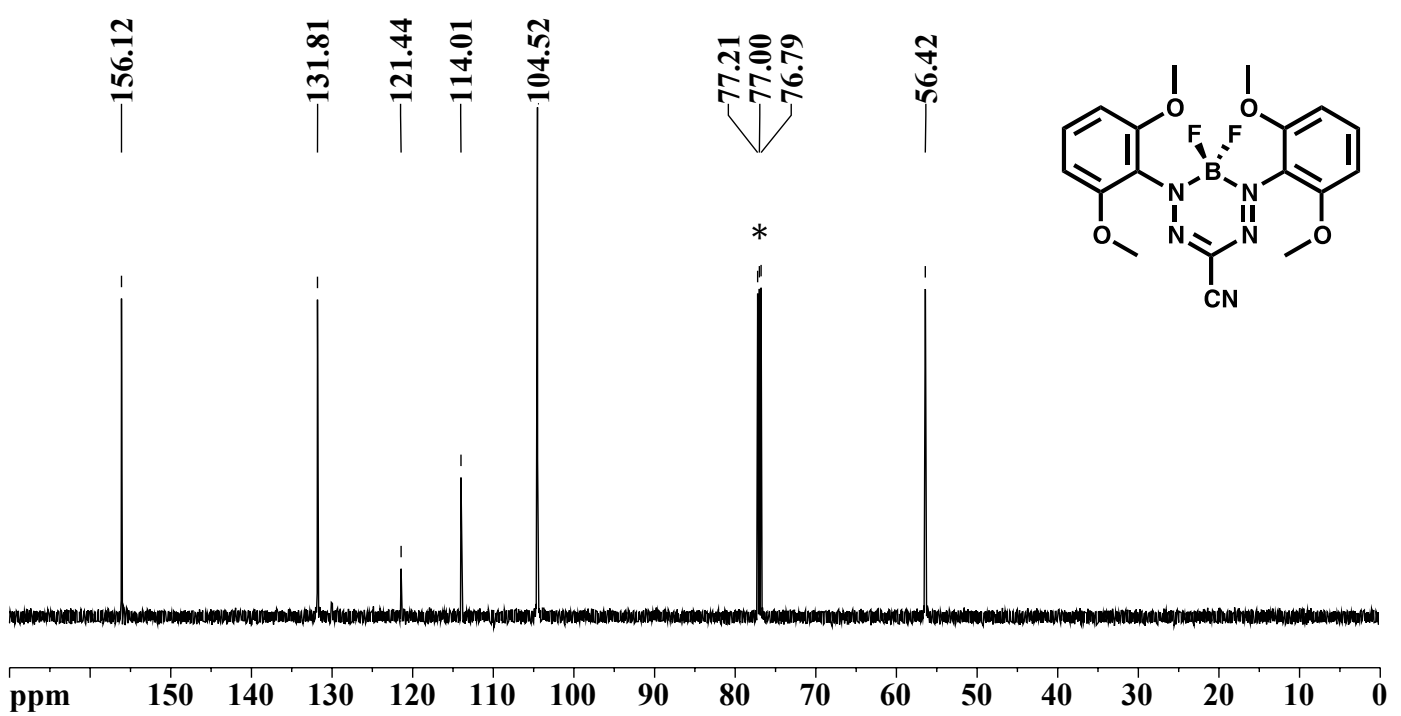

Fig. S4 ${ }^{13} \mathrm{C}\left\{{ }^{1} \mathrm{H}\right\}$ NMR spectrum of $\mathrm{BF}_{2}$ 3-cyanoformazanate $\mathbf{5 c}$ in $\mathrm{CDCl}_{3}$. Asterisk denotes solvent signal. 
a

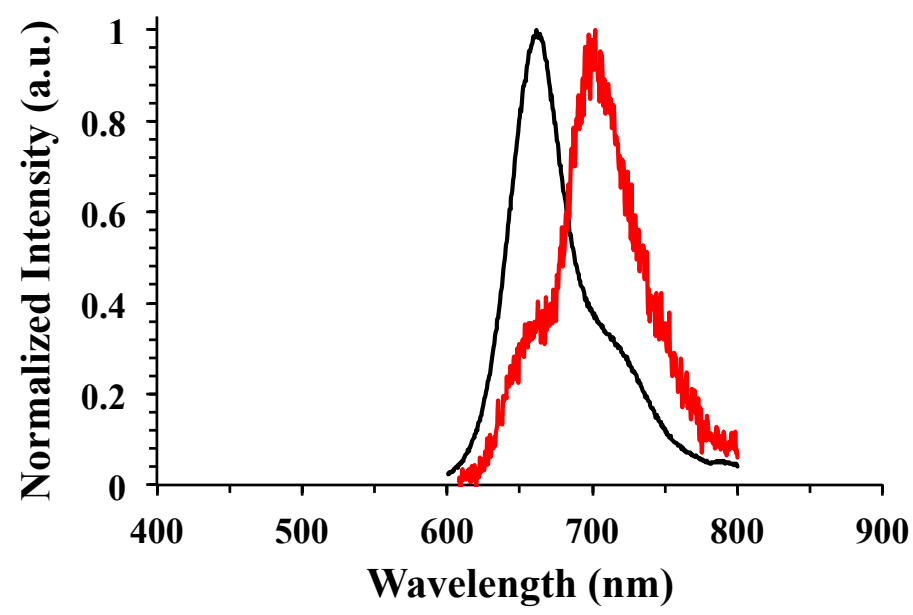

b

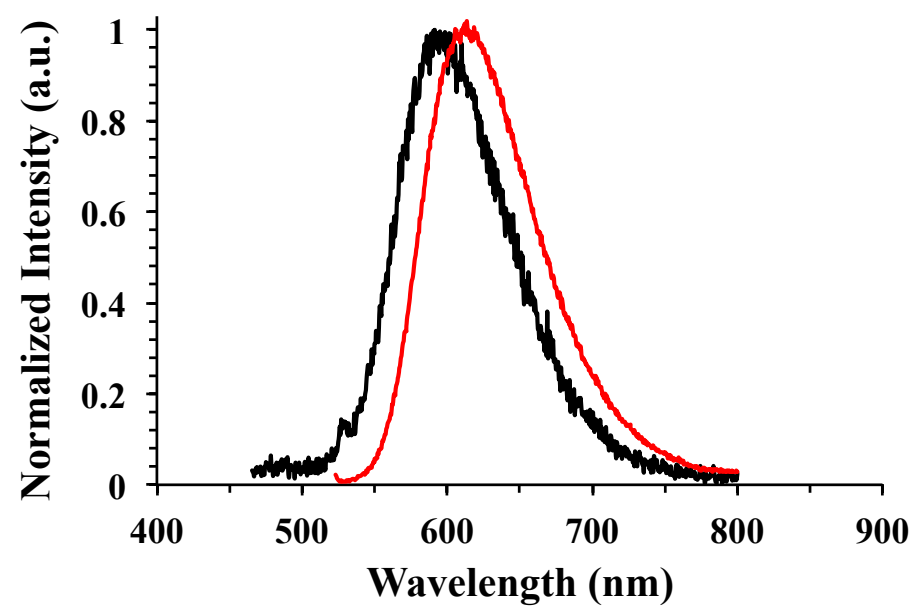

c

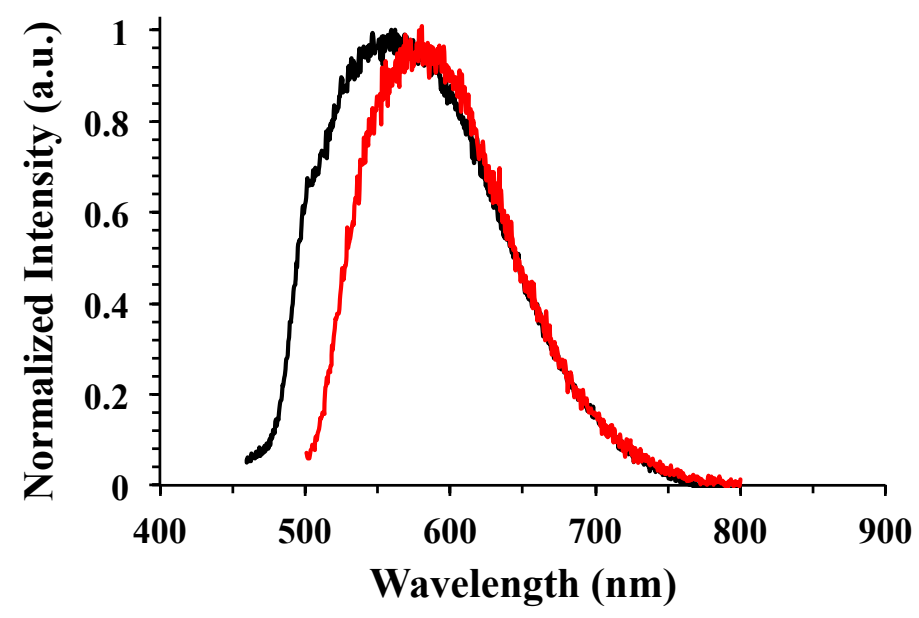

Fig. S5 Normalized UV-vis emission spectra of $\mathbf{5 a}(\mathrm{a}), \mathbf{5 b}(\mathrm{b})$, and $\mathbf{5 c}$ (c) in pure THF solution (black line; $250 \mu \mathrm{M})$ and in a THF-water mixture $\left(f_{\mathrm{w}}=95 \%\right.$; red line; $\left.250 \mu \mathrm{M}\right)$. 


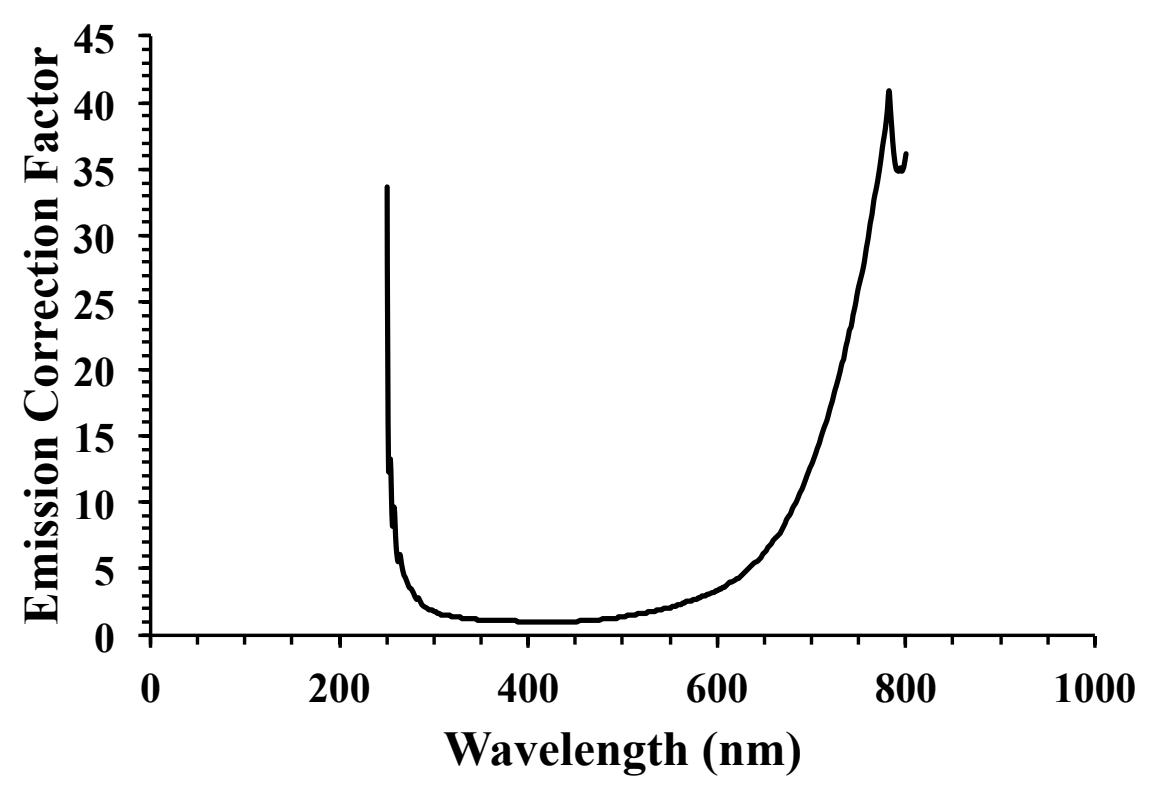

Fig. S6 Wavelength-dependent emission intensity correction provided by Photon Technology International.

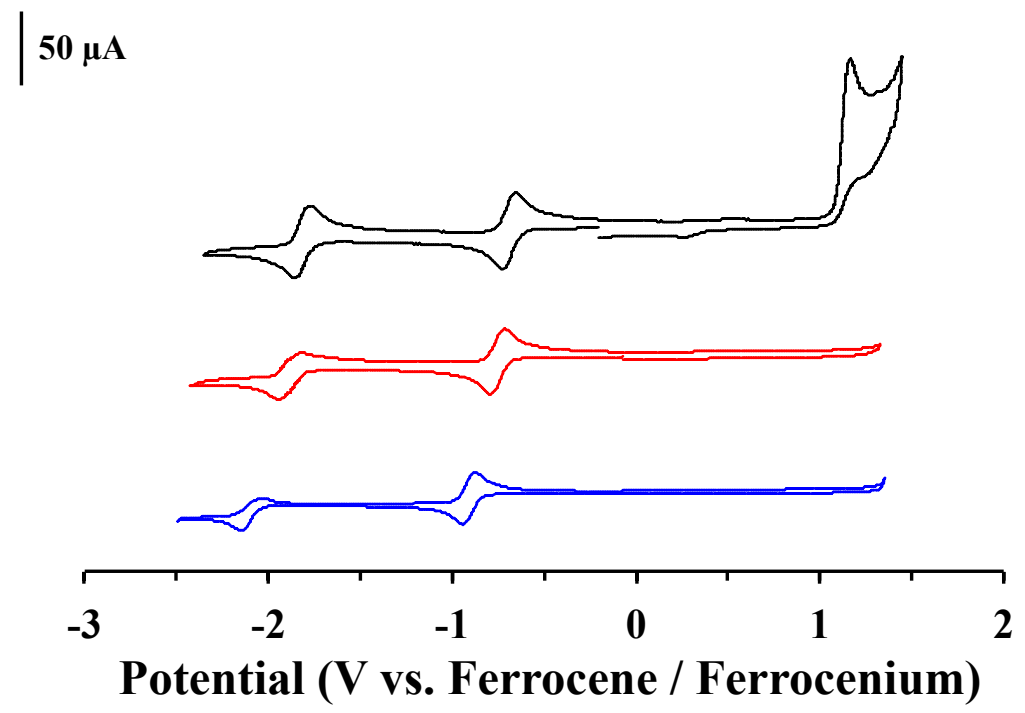

Fig. S7 Cyclic voltammograms of $\mathrm{BF}_{2}$ 3-cyanoformazanates $5 \mathbf{a} \quad(\mathrm{Ar}=4-$ methoxyphenyl; black line), 5b (Ar = 2-methoxyphenyl; red line), and $\mathbf{5 c}(\mathrm{Ar}=2,6-$ dimethoxyphenyl; blue line) recorded in dry, degassed acetonitrile containing $\sim 1 \mathrm{mM}$ analyte and $0.1 \mathrm{M} \mathrm{nBu}_{4} \mathrm{NPF}_{6}$ at a scan rate of $100 \mathrm{mV} \mathrm{s}^{-1}$. 
Table S2. X-ray diffraction data collection and refinement details for 5c.

\begin{tabular}{|c|c|}
\hline & $5 c$ \\
\hline Chemical Formula & $\mathrm{C}_{18} \mathrm{H}_{18} \mathrm{BF}_{2} \mathrm{~N}_{5} \mathrm{O}_{4}$ \\
\hline Formula Weight $\left(\mathrm{g} \mathrm{mol}^{-1}\right)$ & 417.18 \\
\hline Crystal Dimensions (mm) & $0.311 \times 0.309 \times 0.177$ \\
\hline Crystal Color and Habit & orange plate \\
\hline Crystal System & orthorhombic \\
\hline Space Group & Pbca \\
\hline Temperature, $(\mathrm{K})$ & 110 \\
\hline$a(\AA)$ & $14.740(3)$ \\
\hline$b(\AA)$ & $14.827(3)$ \\
\hline$c(\AA)$ & $18.170(4)$ \\
\hline$\alpha\left(^{\circ}\right)$ & 90 \\
\hline$\beta\left(^{\circ}\right)$ & 90 \\
\hline$\gamma\left({ }^{\circ}\right)$ & 90 \\
\hline$V\left(\AA^{3}\right)$ & $3971.1(15)$ \\
\hline$Z$ & 8 \\
\hline$\rho\left(\mathrm{g} \mathrm{cm}^{-3}\right)$ & 1.396 \\
\hline$\lambda(\AA)$ & $1.54178\left(\mathrm{Cu}_{\mathrm{K} \alpha}\right)$ \\
\hline$\mu\left(\mathrm{cm}^{-1}\right)$ & 0.957 \\
\hline Diffractometer Type & $\begin{array}{l}\text { Nonius KappaCCD } \\
\text { Apex } 2\end{array}$ \\
\hline $\mathrm{R}_{\text {merge }}$ & 0.0354 \\
\hline $\mathrm{R}_{1}[\mathrm{I}>2 \sigma(\mathrm{I})]$ & 0.0296 \\
\hline$\omega \mathrm{R}_{2}[\mathrm{I}>2 \sigma(\mathrm{I})]$ & 0.0740 \\
\hline $\mathrm{R}_{1}$ (all data) & 0.0313 \\
\hline$\omega \mathrm{R}_{2}$ (all data) & 0.0753 \\
\hline GOF & 1.034 \\
\hline
\end{tabular}


Table S3. Selected bond lengths $(\AA)$ and angles $\left(^{\circ}\right)$ for $\mathrm{BF}_{2}$ 3-cyanoformazanate complexes 5a-c.

\begin{tabular}{|c|c|c|c|c|}
\hline & & & $\mathbf{5} \mathbf{b}^{2}$ & $5 c$ \\
\hline $\mathrm{N} 1-\mathrm{N} 2$ & $1.307(2)$ & $1.2987(6)$ & $1.3040(16)$ & $1.2980(13)$ \\
\hline $\mathrm{N} 3-\mathrm{N} 4$ & $1.304(2)$ & - & $1.3038(16)$ & $1.2973(13)$ \\
\hline $\mathrm{C} 1-\mathrm{N} 2$ & $1.340(3)$ & $1.3443(5)$ & $1.3404(19)$ & $1.3435(15)$ \\
\hline $\mathrm{C} 1-\mathrm{N} 4$ & $1.335(3)$ & - & $1.3438(18)$ & $1.3486(15)$ \\
\hline N1-N2-C1 & $116.75(18)$ & $116.42(4)$ & $116.09(11)$ & $114.50(9)$ \\
\hline N1-B1-N3 & $106.85(17)$ & - & $101.99(10)$ & $100.14(8)$ \\
\hline N1-B1-N1' & - & $102.63(5)$ & - & - \\
\hline $\mathrm{N} 2-\mathrm{C} 1-\mathrm{N} 4$ & $130.0(2)$ & - & $126.85(12)$ & $126.08(10)$ \\
\hline N2-C1-N2' & - & $127.22(6)$ & - & - \\
\hline dihedral angles ${ }^{b}$ & $15.3,21.4$ & $47.7,47.7$ & $62.0,60.5$ & $74.6,66.6$ \\
\hline
\end{tabular}

${ }^{a}$ The asymmetric unit determined for 5a contains two unique molecules. ${ }^{1 b}$ Dihedral angle between the N1 and N3 aryl substituents and the $\mathrm{N}_{4}$ plane. 
$\mathbf{a}$

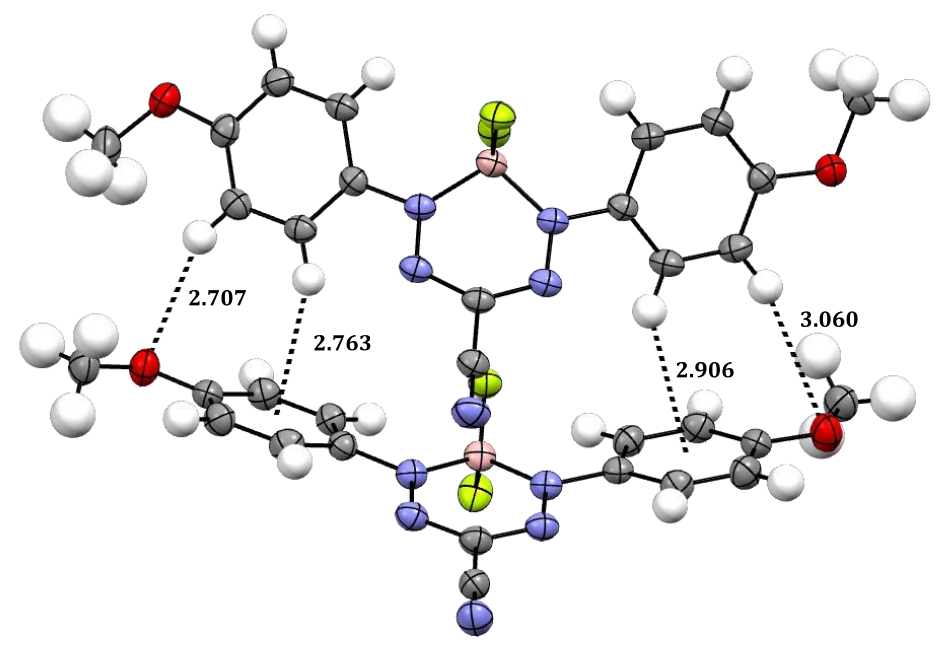

b

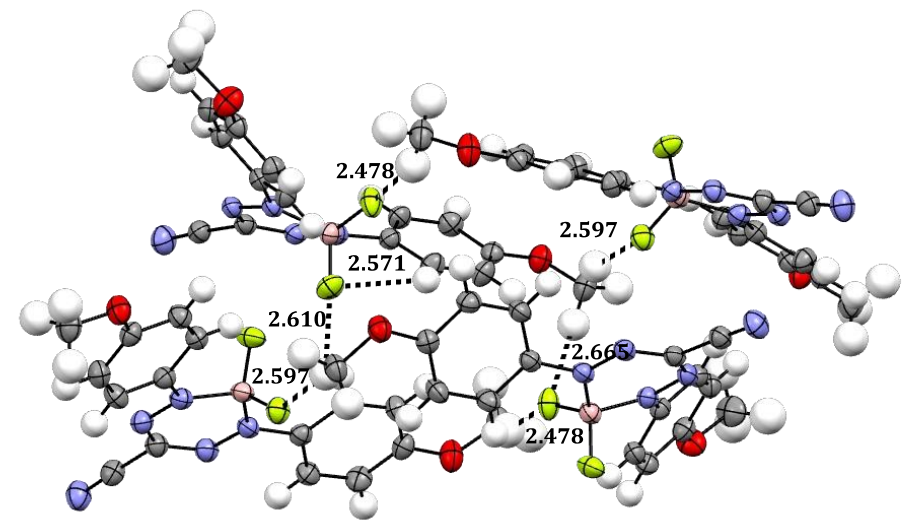

Fig. S8 Intermolecular solid-state $\mathrm{CH} \bullet \cdot \mathrm{O}, \mathrm{CH} \cdots \pi$ (a) and $\mathrm{CH} \bullet \cdot \mathrm{F}$ (b) interactions for 5a. Anisotropic displacement ellipsoids are shown at $50 \%$ probability. All distances are quoted in $\AA$. 

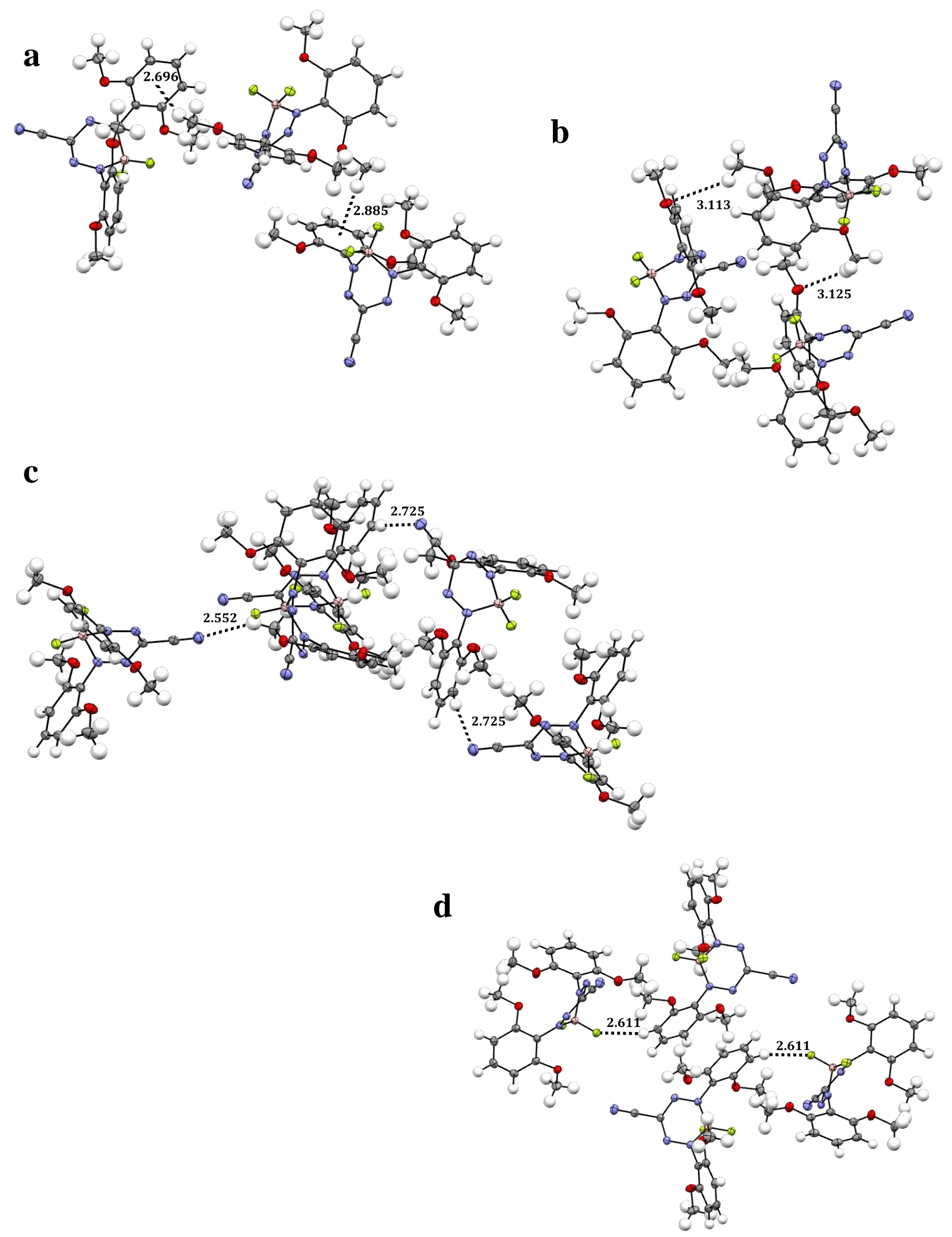

Fig. S9 Intermolecular solid-state $\mathrm{CH} \bullet \bullet \pi(\mathrm{a}), \mathrm{CH} \cdots \mathrm{O}$ (b), $\mathrm{CH} \cdots \mathrm{N}$ (c), and $\mathrm{CH} \cdots \mathrm{F}$ (d) interactions for 5c. Anisotropic displacement ellipsoids are shown at 50\% probability. All distances are quoted in $\AA$. 


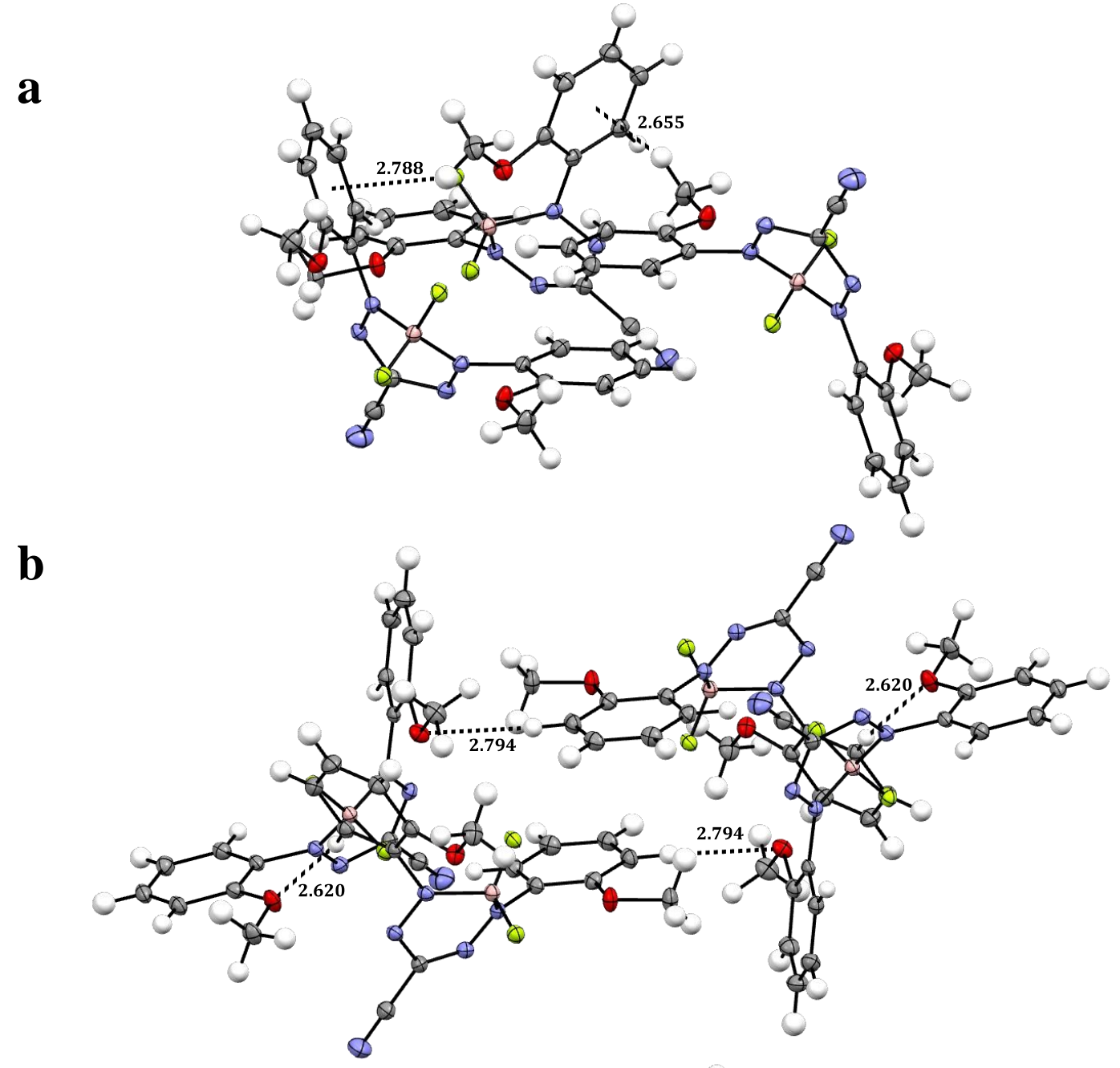

C

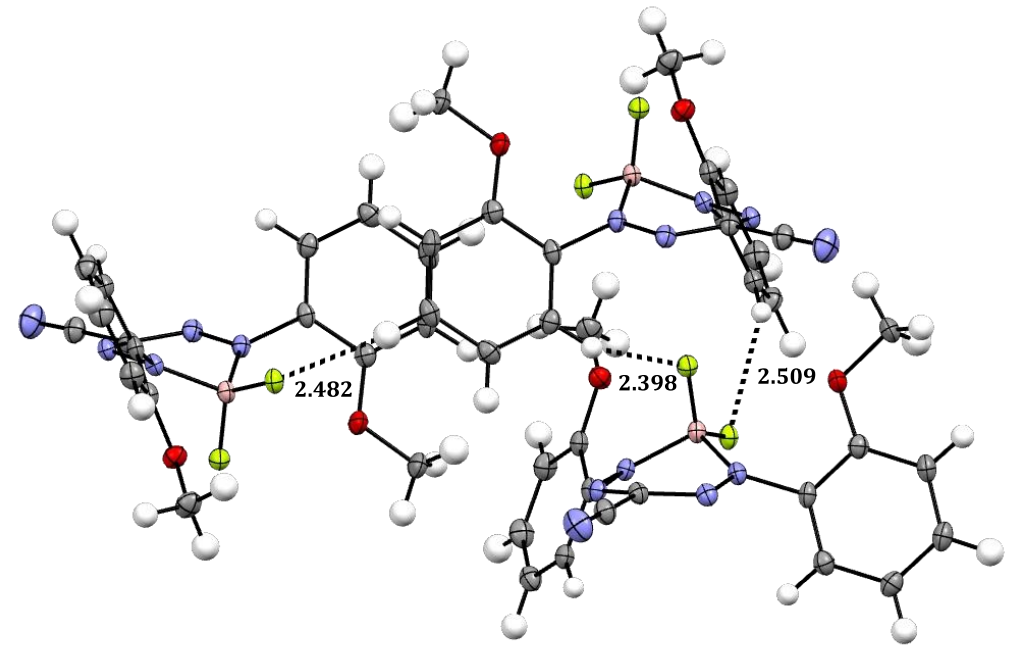

Fig. S10 Intermolecular solid-state $\mathrm{CH} \bullet \bullet \pi(\mathrm{a}), \mathrm{CH} \bullet \bullet \mathrm{O}$ (b), and $\mathrm{CH} \bullet \bullet \mathrm{F}$ (c) interactions for 5b. Anisotropic displacement ellipsoids are shown at $50 \%$ probability. All distances are quoted in $\AA$. 
$\mathbf{a}$

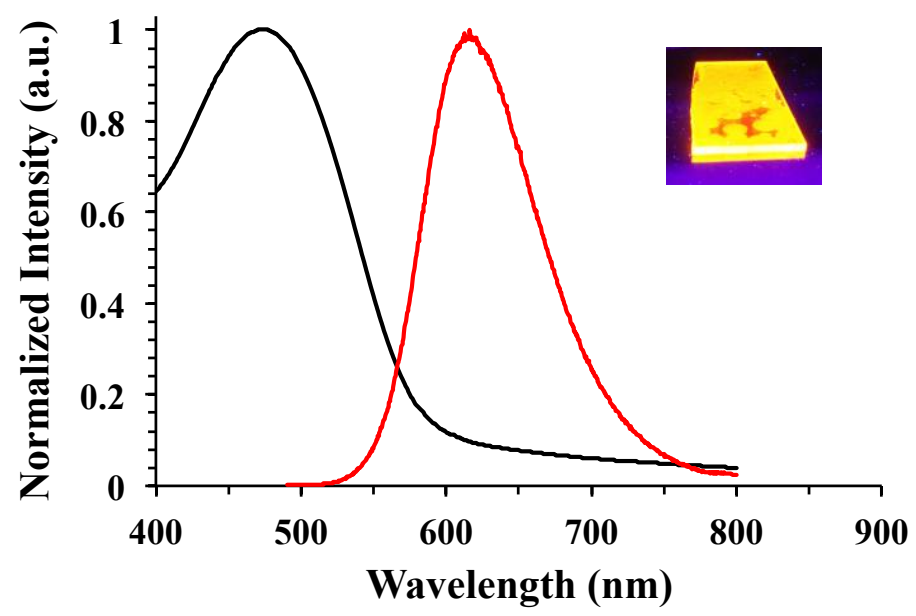

b

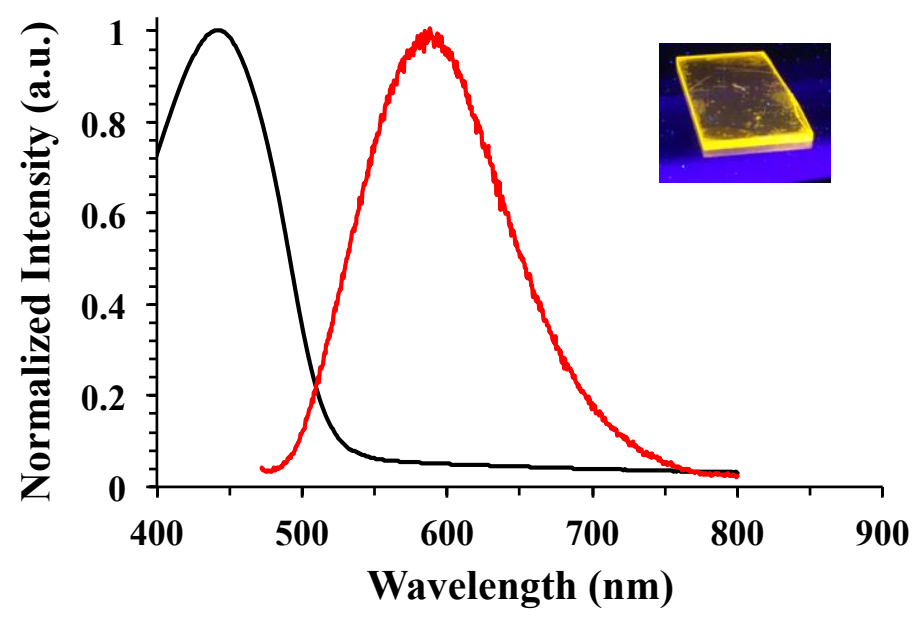

Fig. S11 Normalized UV-vis absorption (black line) and emission (red line) spectra of thin films of $\mathbf{5 b}$ (a) and $\mathbf{5 c}$ (b). Insets provide a visual representation of the emission under UV irradiation $(365 \mathrm{~nm})$. 


\section{References}

1 S. M. Barbon, P. A. Reinkeluers, J. T. Price, V. N. Staroverov and J. B. Gilroy, Chem. Eur. J., 2014, 20, 11340.

2 R. R. Maar, S. M. Barbon, N. Sharma, H. Groom, L. G. Luyt and J. B. Gilroy, Chem. Eur. J., 2015, 21, 15589.

3 S. Fery-Forgues and D. Lavabre, J. Chem. Educ., 1999, 76, 1260.

4 Bruker-AXS, SAINT version 2013.8, 2013, Bruker-AXS Madison, WI 53711, USA.

5 Bruker-AXS, SADABS version 2012.1, 2012, Bruker-AXS, Madison, WI 53711, USA.

6 G. M. Sheldrick, Acta Cryst., 2015, A71, 3.

7 G. M. Sheldrick, Acta Cryst., 2008, A64, 112.

8 K. Suzuki, A. Kobayashi, S. Kaneko, K. Takehira, T. Yoshihara, H. Ishida, Y. Shiina, S. Oishi and S. Tobita, Phys. Chem. Chem. Phys., 2009, 11, 9850. 